\title{
Adsorption of arsenic using low cost adsorbents: guava leaf biomass, mango bark and bagasse
}

\author{
Devendra Mohan $^{1, *}$, Markandeya ${ }^{1}$, S. Dey ${ }^{1}$, S. B. Dwivedi ${ }^{1}$ and S. P. Shukla ${ }^{2}$ \\ ${ }^{1}$ Department of Civil Engineering, Indian Institute of Technology (BHU), Varanasi 221 005, India \\ ${ }^{2}$ Department of Civil Engineering, Institute of Engineering and Technology, Lucknow 226021 , India
}

\begin{abstract}
Adsorbents prepared from inexpensive materials of guava leaf biomass, mango bark and bagasse were studied for As(III) removal from the aqueous solution. The effects of $\mathrm{pH}$, contact time, initial As(III) concentration and adsorbent dosage on the adsorption of $\operatorname{As}$ (III) were studied using batch experiments. Adsorption process was also verified with Langmuir, Freundlich, Temkin and Redlich-Peterson models. Langmuir isotherm fitted best in the experimental data. Application of Langmuir isotherm to the system yielded the maximum capacities of $1.35 \mathrm{mg} \mathrm{g}^{-1}$, $1.25 \mathrm{mg} \mathrm{g}^{-1}$ and $1.05 \mathrm{mg} \mathrm{g}^{-1}$ for bagasse, mango bark and guava leaf biomass respectively, in the range of As(III) concentration as $10-140 \mathrm{mg} \mathrm{l}^{-1}$. The dimensionless equilibrium parameter, $R_{L}$, signifies favourable adsorption of $\mathrm{As}$ (III) on all adsorbents and was observed to be in the range of $0.029-0.294,0.021-$ 0.235 and $0.021-0.234$, for bagasse, mango bark and guava leaf biomass respectively $\left(0<R_{L}<1\right)$. The adsorption process was observed to follow pseudosecond-order kinetic model.
\end{abstract}

Keywords: Adsorption, arsenite ion-As(III), isotherms, kinetics, low-cost adsorbents.

DURING the past few decades, arsenic has gradually been identified around the world as one of the most toxic substances in water and wastewater, which weakens the immune system and threatens human health ${ }^{1}$. Arsenic content in groundwater varies with the geographical location, geological conditions and anthropogenic activities. Human activities resulting in arsenic in groundwater are mainly owing to arsenical pesticides, fertilizers, desiccants, preservatives, dust from the burning of fossil fuels and disposal of industrial and animal wastes, etc. ${ }^{2,3}$. Approximately $97 \%$ of the arsenic produced enters the environment through the end-product containing As(III) and the remaining $3 \%$ from the semi-metal employed As metallurgical additives, especially to lead and copper to produce their alloys. Inorganic arsenic of geogenic (natural) origin is also found in groundwater in certain parts of the world, owing to volcanic action followed by

*For correspondence. (e-mail: devmohan9@gmail.com) low temperature volatization ${ }^{4}$. Arsenic may also be naturally present in all rocks and sediments forming aquifers that are tapped for drinking 5 . It has been reported that areas affected by geothermal, mining and industrial activities may suffer from presence of large range of arsenic varying from 0.5 to $5000 \mu \mathrm{g} \mathrm{l}^{-1}$ (ref. 6). There are 21 arsenic affected countries worldwide and out of these, Bangladesh (concentration greater than $0.2 \mathrm{mg} \mathrm{l}^{-1}$ ) and West Bengal in India (highest $470 \mathrm{mg} \mathrm{l}^{-1}$ ) are at high health risk due to arsenic contaminated groundwater ${ }^{7}$.

In groundwater, arsenic may combine with oxygen and form inorganic pentavalent arsenate, $\mathrm{As}(\mathrm{V})$ and trivalent arsenite, As(III) depending on the $\mathrm{pH}$ and redox conditions $^{8}$. As(III) is more stable than $\mathrm{As}(\mathrm{V})$ due to the electronic configuration and also, relatively more toxic because it can bind with higher affinity to sulphhydryl groups that have the capability to react with a variety of proteins, thus, inhibiting their activity ${ }^{9}$. It has been established that exposure to arsenic may lead to both, acute as well as chronic toxicity, resulting in many adverse impacts on human health like haematological, hepatic, renal, dermal, neurological, developmental, reproductive, immunologic, genotoxic, mutagenic, carcinogenic, haematological/hepatic including other biological effects ${ }^{4}$. Certain severe diseases faced by humans due to consumption of arsenic contaminated water include cancers of liver, lungs, skin, kidney and bladder; pigmentation changes, hyperkeratosis, neurological and gastrointestinal disorders, muscular weakness, bone marrow problems, cardiovascular problems, etc. ${ }^{4}$. Therefore, arsenic contamination of groundwater worldwide is an environmental issue of major concern that requires serious attention immediately. To overcome this situation, earlier provisional guidelines of WHO and USEPA has brought down the drinking water quality standard from 50 to $10 \mathrm{ppb}^{10,11}$.

Several technologies are available now for the treatment of arsenic contaminated water ${ }^{6}$, amongst which the most common techniques are oxidation/precipitation/ filtration $^{12}$, coagulation/electro-coagulation/co-precipitation $^{13}$, ion exchange resin ${ }^{14}$, membrane techniques like ultra/nano-filtration/reverse osmosis/electrolysis, etc. ${ }^{15}$.

The conventional practice of arsenic removal (at large scale) is to first oxidize $\mathrm{As}(\mathrm{III})$ into $\mathrm{As}(\mathrm{V})$, employing 
either chemical or biological routes and then, use any media like iron/manganese or alumina for adsorption. Though these chemical methods are simple, large amounts of toxic sludges are produced that require further treatment before the ultimate disposal. Ion-exchange resins require high cost, high-tech operation and maintenance and regeneration (feasible partially) and also create sludge disposal problems. Membrane-based techniques also need high initial as well as operation and maintenance costs along with rejection of water in sizeable quantities. The other limitation associated with most of the conventional treatment methods is efficiency of the treatment, i.e. they are not much effective at lower concentrations and even after treatment, the residual concentrations may remain higher than the permissible limit with respect to the drinking water quality standards, i.e. $10 \mu \mathrm{g} \mathrm{l}^{-1}$ (ref. 16).

The process of adsorption involves a solid phase (adsorbent) and a liquid phase containing dissolved species to be adsorbed. Agricultural waste-materials are usually composed of lignin, cellulose, lipids, proteins, polysaccharides, hydrocarbons, ash and many other compounds as a variety of functional groups ${ }^{17}$. These groups present on the solid materials cause affinity to adsorb the ionic species (adsorbate) present in the solution. This phenomenon depends on the bond linkages between species of the adsorbate in solution and molecules of the solid materials. Any solid material may be employed as adsorbent if it has sufficient affinity to adsorb the target species. Local and abundant availability, low cost of preparation and high capacity to adsorb make an effective adsorbent ${ }^{18}$. The bond linkages between the metal species and molecules of adsorbent depend on a complex mechanism through which metal species are diffused to the adsorbent surface and its inner pores. Many mechanisms have been proposed to explain the removal at the adsorbent surface and pores involving chemisorption, complexation, ion exchange, chelation, physical forces, entrapment in inter and intra-fibrillar capillaries, etc. ${ }^{19}$.

Proper understanding of the adsorption mechanism, rate of adsorption, maximum adsorption capacity and suitable $\mathrm{pH}$ range, contact time to reach equilibrium, initial adsorbate concentration and dosage of adsorbent are essential parameters needed for the system design. To understand the kinetics and equilibrium isotherms, batch study has been undertaken to investigate various related parameters fitting into appropriate models. Finally, these parameters were correlated to understand the adsorption mechanism for the more toxic form, i.e. As(III), from the water on the surface of biosorbents prepared from agricultural wastes like bagasse, mango bark and biomass of guava leaf.

As an alternative or a part of tertiary water treatment, adsorption has long been recognized as an effective technique and it is being used, specifically more commonly in the developing world to treat arsenic contaminated water up to the desired level of efficiency. Researchers had put in efforts to study new adsorbents that are easily and locally available, as well as have low-cost of preparation, operation and handling ${ }^{20,21}$. Now-a-days, various solid wastes generated as byproducts of industry/agriculture are under study, to assess the adsorption potential for arsenite ions present in water. With the objective of developing novel and low-cost adsorbents to remove As(III) from contaminated water, guava leaf biomass, mango bark and bagasse have been employed as inexpensive agriculture wastes and their adsorption capacities have been evaluated for As(III) removal under equilibrium and dynamic experimental conditions.

\section{Materials and methods}

\section{Adsorbents}

The guava leaf biomass, mango bark and bagasse were collected within the campus of Indian Institute of Technology (BHU), Varanasi, India. Subsequently, these were cleaned with distilled water and then air dried in hot air oven at a temperature of $60^{\circ} \mathrm{C}$ for $24 \mathrm{~h}$. Later, these were crushed and passed through British standard sieves in the range of $0.425-1.180 \mathrm{~mm}$. The adsorbents were activated by treating with acids, which increase effectiveness of adsorption by enhancing active sites per unit surface area. This also provides better ion exchange properties due to formation of new functional groups ${ }^{2-24}$. Several acidic treatments were experimented to improve the adsorption properties of the sorbents. Finally, $\mathrm{HCl}(0.1 \mathrm{~N})$ was used to activate the biomass derived from guava leaf, mango bark and bagasse. Activation was performed by treating $1 \mathrm{~g}$ of the residue retained on screens with $100 \mathrm{ml}$ of acidic solution for $6 \mathrm{~h}$ at $55^{\circ} \mathrm{C}$ under continuous stirring and subsequently followed by filtration and oven drying at $55^{\circ} \mathrm{C}$ for $24 \mathrm{~h}$. The oven dried sample was washed with distilled water to remove residual acid from the surface until the runoff was visibly clear. Then, this sample was dried again at $110^{\circ} \mathrm{C}$ for $12 \mathrm{~h}$ and then kept in capped bottles.

\section{Adsorbate}

All chemicals used were of analytical grades. A stock As(III) solution $(1 \mathrm{ml}=1000 \mu \mathrm{g}$ As) was prepared by dissolving $0.1320 \mathrm{~g}$ of $\mathrm{As}_{2} \mathrm{O}_{3}$ in a mixture of $50 \mathrm{ml}$ of reagent grade water and $1 \mathrm{ml}$ conc. $\mathrm{NH}_{4} \mathrm{OH}$. It was heated gently to dissolve completely, cooled and acidified with $2 \mathrm{ml}$ conc. $\mathrm{HNO}_{3}$. Then, it was diluted to $100 \mathrm{ml}$ with reagent grade water.

\section{Batch adsorption studies}

Batch adsorption studies were conducted in $250 \mathrm{ml}$ erlenmeyer flask by agitating a pre-weighted amount of 
the adsorbent with $100 \mathrm{ml}$ of aqueous As(III) solution for a fixed time $(100 \mathrm{~min})$ period at constant temperature $\left(25^{\circ} \pm 1^{\circ} \mathrm{C}\right)$ on a water bath shaker at $100 \mathrm{rpm}$. The $\mathrm{pH}$ was maintained (ranging from 2 to 8 ) at a desired value \pm 0.1 using $0.01-0.05 \mathrm{~N} \mathrm{H}_{2} \mathrm{SO}_{4}$ and $\mathrm{NaOH}$ at an interval of every $1-2 \mathrm{~h}$, or as and when needed. The supernatants were passed through filter paper number 42 (Whatman). Adsorption isotherm study was also carried out by varying concentration of $\mathrm{As}$ (III) from 10 to $140 \mathrm{mg} \mathrm{l}^{-1}$, while maintaining the adsorbent dosage of $8 \mathrm{~g}$ (bagasse and mango bark) and $9 \mathrm{~g}$ (guava leaf), placed in the solution taking equilibrium time of $100 \mathrm{~min}$. The effects of variation in parameters like $\mathrm{pH}$, contact time and initial concentration were studied keeping constant adsorbent dosage of $8 \mathrm{~g}$ (bagasse and mango bark) and $9 \mathrm{~g}$ (guava leaf) in contact with As(III) solution, having concentration of $100 \mathrm{mg} \mathrm{l}^{-1}$.

Effect of adsorbent dosage was studied at $100 \mathrm{mg} \mathrm{l}^{-1}$ of As(III) concentration with varying adsorbent dosage from 1 to $12 \mathrm{~g}$ in the solution. The concentration of free As(III) ion in the filtrate was determined using Arsenator (make Wagtech, UK). The values were also verified randomly as specified in the procedure 3500-A (ref. 25) using atomic absorption spectrophotometer (make Shimadzu, model AA 6800) with continuum background correction. For the atomic absorption spectrophotometer, all measurements were based on integrated absorbance and performed at $193.7 \mathrm{~nm}$ by using a hollow cathode lamp. The experiments were performed in triplicate and the average values were considered.

Amount of the adsorbed As(III) was calculated by finding the difference between the initial and residual amounts of As(III) in the solution divided by mass of the adsorbent used, as shown in the mass balance eq. (1). Percentage removal of As(III) was determined using eq. (2).

$$
\begin{aligned}
& q=\frac{\left(C_{\mathrm{o}}-C_{\mathrm{e}}\right) \times V}{m_{\mathrm{s}}} \\
& R(\%)=\frac{\left(C_{\mathrm{o}}-C_{\mathrm{e}}\right)}{C_{\mathrm{o}}} \times 100
\end{aligned}
$$

where $q$ is the amount of As(III) adsorbed by the adsorbent $\left(\mathrm{mg} \mathrm{g}^{-1}\right), C_{\mathrm{o}}$ and $C_{\mathrm{e}}$ are the initial and equilibrium concentrations of As(III) in the solution ( $\mathrm{mg} \mathrm{l}^{-1}$ ), $V$ the total volume of the sample $(100 \mathrm{ml}), m_{\mathrm{s}}$ the mass of adsorbent used for adsorption ( $\mathrm{g}$ ) and $R$ is the percentage of As(III) removal efficiency of the corresponding adsorbent.

\section{Results and discussion}

Adsorption percentage of As(III) removal on activated powder of bagasse, mango bark and guava leaf were observed at initial concentration of $10 \mathrm{mg} \mathrm{l}^{-1}$ under optimized $\mathrm{pH}$ range and adsorbent dosage. Removal was reported as $95.2 \%, 97.2 \%$ and $94.4 \%$ for bagasse, mango bark and guava leaf respectively. Maximum adsorption capacity at $140 \mathrm{mg} \mathrm{l}^{-1}$ of As(III) was found to be $1.191 \mathrm{mg} \mathrm{g}^{-1}, 1.155 \mathrm{mg} \mathrm{g}^{-1}$ and $0.968 \mathrm{mg} \mathrm{g}^{-1}$, for bagasse, mango bark and guava leaf respectively. Various researchers such as Singh and $\mathrm{Pant}^{26}$ and Vaishya and Gupta $^{27}$ have compared the adsorbent capacities for treatment of drinking water, groundwater and wastewater. This comparison with the adsorbent capacity and initial concentration of As(III) in case of previously studied adsorbents revealed that the adsorbents prepared from bagasse, mango bark and guava leaf biomass can be effectively used as alternate economical materials for removal of As(III) from wastewater.

\section{Batch studies}

Effect of $p H$ : Studies indicate that As(III) ionic species is $\mathrm{pH}$ dependent and it is stable at $\mathrm{pH}<9$ in the form of neutral $\mathrm{H}_{3} \mathrm{AsO}_{3}$, pH 9-12 as $\mathrm{H}_{2} \mathrm{AsO}_{3}$, pH $12-13$ as $\mathrm{HAsO}_{3}^{2-}$ and $\mathrm{pH}>13$ as $\mathrm{AsO}_{3}^{3-}$ respectively ${ }^{28}$. Dissociation mechanism of arsenite species is reported by Tamas et $a l .{ }^{29}$ in terms of its acid dissociation constant $\left(\mathrm{pK}_{\mathrm{a}}\right)$. The larger the value of $\mathrm{pK}_{\mathrm{a}}$, lower the probability to dissociate at any $\mathrm{pH}$ and hence, it is relatively difficult to dissociate $\mathrm{H}_{2} \mathrm{AsO}_{3}$ and $\mathrm{H}_{2} \mathrm{AsO}_{3}^{-}$. Equilibrium data of the experiments in this study have also confirmed the species $\mathrm{H}_{3} \mathrm{AsO}_{3}$ as an active arsenite species by giving effective adsorption of $\mathrm{As}(\mathrm{III})$ in the $\mathrm{pH}$ range of $2-8$ at the surface of all the three adsorbents.

Increase in As(III) removal was observed from $23 \%$ to $73 \%$ (bagasse), $7 \%$ to $62 \%$ (mango bark) and $14 \%$ to $68 \%$ (guava leaf biomass) at increasing rate when $\mathrm{pH}$ was raised from 2 to 6 ; only slight removal could take place in the $\mathrm{pH}$ range of $6-7$ (Figure 1). The maximum removal of $87 \%$ was observed at $\mathrm{pH} 7.5$ for bagasse, $84 \%$ at $\mathrm{pH} 6.5$ for mango bark and $83 \%$ at $\mathrm{pH} 6$ for guava leaf biomass. Further increase in $\mathrm{pH}$ beyond these values showed slight reduction in $\mathrm{As}$ (III) removal. It was observed that $\mathrm{pH} 7.5$, 6.5 and 6.0 can be considered as optimum $\mathrm{pH}$ value for As(III) removal by adsorption on the adsorbent surfaces of bagasse, mango bark and guava leaf biomass respectively. The $\mathrm{pH}$ dependence on adsorption can be understood as affinity of each arsenic species to the adsorbent is different and therefore, the degree of adsorption of As(III) on the adsorbent surfaces of bagasse, mango bark and guava leaf varied with the arsenic species and thus, with $\mathrm{pH}$ value of the solution. Salman et al. ${ }^{30}$ reported that the adsorption was more effective on acidtreated adsorbents and therefore, adsorbents of guava leaf biomass, bagasse and mango bark were activated using $0.1 \mathrm{~N} \mathrm{HCl}$ at $55^{\circ} \mathrm{C}$. At this temperature, activated adsorbents generally develop acidic surface oxides in the $\mathrm{pH}$ 


\section{RESEARCH ARTICLES}

range of 6-8, while the surfaces of adsorbents become positively charged to adsorb more arsenite ions.

Effect of contact time: Results presented in Figure 2 reveal that the effect of contact time at optimum $\mathrm{pH} 7.5$, 6.5 and 6.0 can be considered as value for As(III) removal by adsorption on bagasse, mango bark and guava leaf biomass respectively. Three stages of adsorption can be observed in each case and these indicate high influence of contact time on removal of As(III) by adsorption. First stage of As(III) uptake at adsorbent surfaces occurred at high rate during 0 to $90 \mathrm{~min}$ and removal up to $83 \%$ for bagasse, $82 \%$ for mango bark and $81 \%$ for guava leaf biomass could be achieved. On further increase in contact time, almost negligible enhancement in adsorption was observed. Therefore from Figure 2, it can be concluded

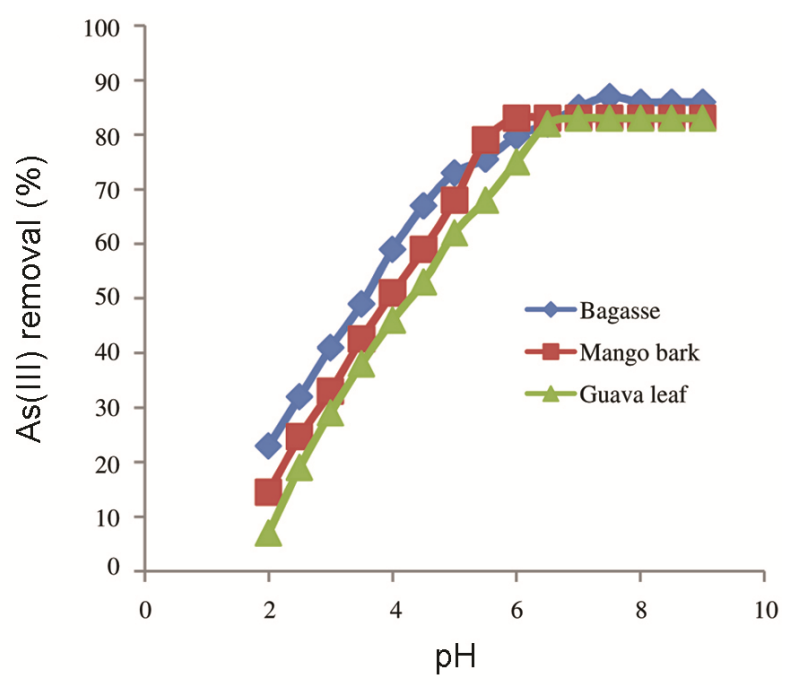

Figure 1. Effect of $\mathrm{pH}$ on $\mathrm{As}(\mathrm{III})$ adsorption.

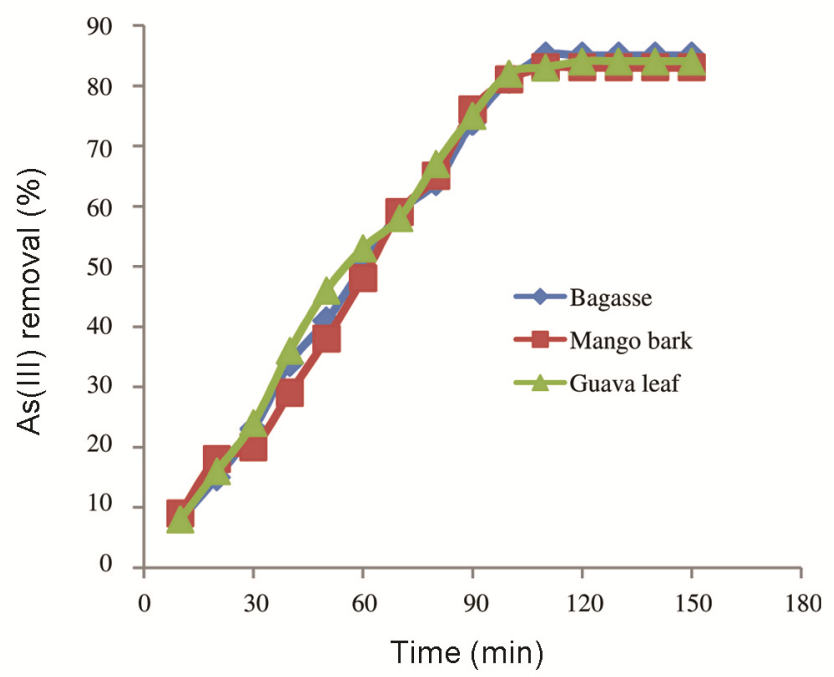

Figure 2. Effect of contact time on As(III) adsorption. that the contact time of 100 min may be considered as an equilibrium time for adsorption of As(III) for all adsorbents while carrying out batch studies in the present case. Adsorption sites with formation of bi-dentate complexes are provided within very short duration and beyond this stage, no adsorbent site remains for further adsorption because saturation was achieved on the adsorbent surfaces $^{31}$.

Effect of initial concentration: Influence of initial concentration of As(III) on removal by adsorption was studied at concentrations varying from 10 to $140 \mathrm{mg} \mathrm{l}^{-1}$, while maintaining the adsorbent dosage $8 \mathrm{~g}$ (bagasse and mango bark) and $9 \mathrm{~g}$ (guava leaf biomass) respectively, in solution at optimized $\mathrm{pH}$ and contact time. Figure 3 shows the effect of initial concentration of As(III) on percentage removal and adsorption capacity. Decrease in percentage removal was observed from $95.4 \%$ to $68.0 \%$ for bagasse, $97.2 \%$ to $68.0 \%$ for mango bark and $96.4 \%$ to $62.2 \%$ for guava leaf biomass, when concentration of solute was increased from 10 to $140 \mathrm{mg} \mathrm{l}^{-1}$ at fixed contact time and $\mathrm{pH}$. The results indicated that a very small reduction in removal occurred, when concentrations varied from 10 to $70 \mathrm{mg} \mathrm{l}^{-1}$; but afterwards, increase in concentration led to rapid reduction in As(III) removal. The drop in percentage As(III) removal is due to increase in the number of As(III) ions for fixed number of adsorbent sites. It was further observed that the surface of mango bark showed the maximum value of removal between 10 and $60 \mathrm{mg} \mathrm{l}^{-1}$ of As(III) concentration compared to guava leaf biomass and bagasse, but the results also indicated that this affinity did not remain so at higher As(III) concentration. Katsoyiannis and Zouboulis ${ }^{32}$ have reported that during physicochemical iron oxidation, arsenate removal was about $80 \%$ for relatively lower initial arsenic concentrations $\left(20-50 \mu \mathrm{g} \mathrm{l}^{-1}\right)$ and it

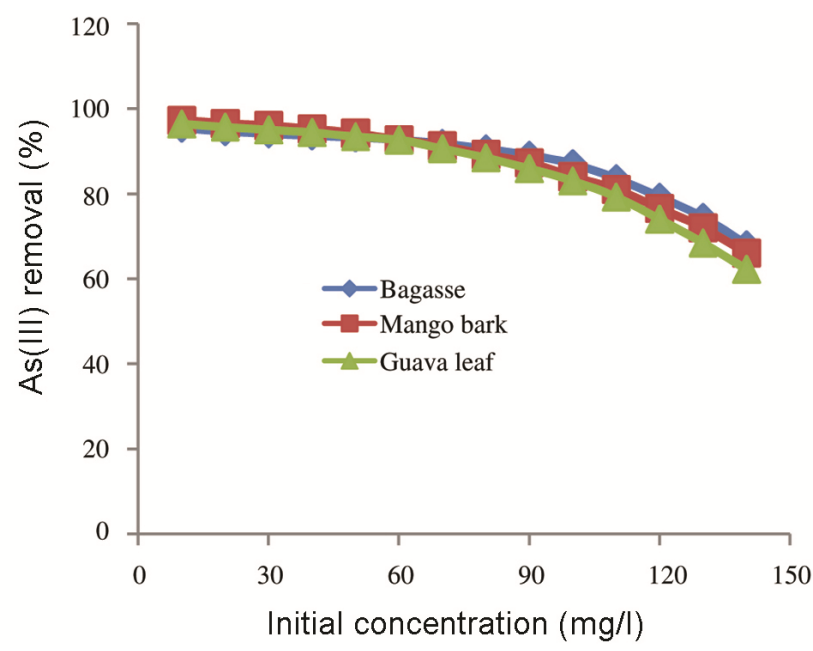

Figure 3. Effect of initial concentration on As(III) adsorption. 
decreased to about $60 \%$, when initial arsenic concentration was increased further to $188 \mathrm{mg}^{-1}$.

Bagasse showed higher affinity compared to mango bark and guava leaf at higher arsenic concentration. However, the same adsorption percentage was observed on each adsorbent at $60 \mathrm{mg}^{-1}$ of arsenic concentration and this indicated equal affinity to adsorb arsenite species at this concentration (Figure 3 ).

Possibility of interference of previously adsorbed species can also not be ruled out and it may reduce As(III) adsorption and desorption from adsorbent molecules, which results ultimately in decreased adsorption capacity. Value of optimum percentage removal at $60 \mathrm{mg} \mathrm{l}^{-1}$ was observed as $89.76 \%$ for bagasse, $88.34 \%$ for mango bark and $85.84 \%$ for guava leaf biomass respectively; while the values for optimum adsorption capacity were $0.974 \mathrm{mg} \mathrm{g}^{-1}$ for bagasse, $0.937 \mathrm{mg} \mathrm{g}^{-1}$ for mango bark and $0.859 \mathrm{mg} \mathrm{g}^{-1}$ for guava leaf biomass.

Effect of adsorbent dosage: Results of the batch studies conducted for determination of adsorbent dosage at initial concentration of As(III) as $60 \mathrm{mg} \mathrm{l}^{-1}$ with varying dosage of 4 to $12 \mathrm{~g}$ under optimized environmental conditions are presented in Figure 4. Increase in As(III) percentage removal was observed with increase in amount of adsorbent dosage. The percentage removal increased from 55\% to $87 \%$ (bagasse), $50 \%$ to $84 \%$ (mango bark) and $46 \%$ to $83 \%$ (guava leaf biomass). Higher percentage removal of As(III) was due to availability of more active adsorbent sites for adsorption at higher adsorbent dosage. But, capacity to adsorb As(III) was not same for each adsorbent dosage. Explanation in terms of adsorption sites can be given using a ratio factor of active adsorbent sites per unit mass of the adsorbents. This factor can also be correlated with apparent energy of sorption defined by Langmuir and the values lower than unity indicate decrease in the adsorption capacity.

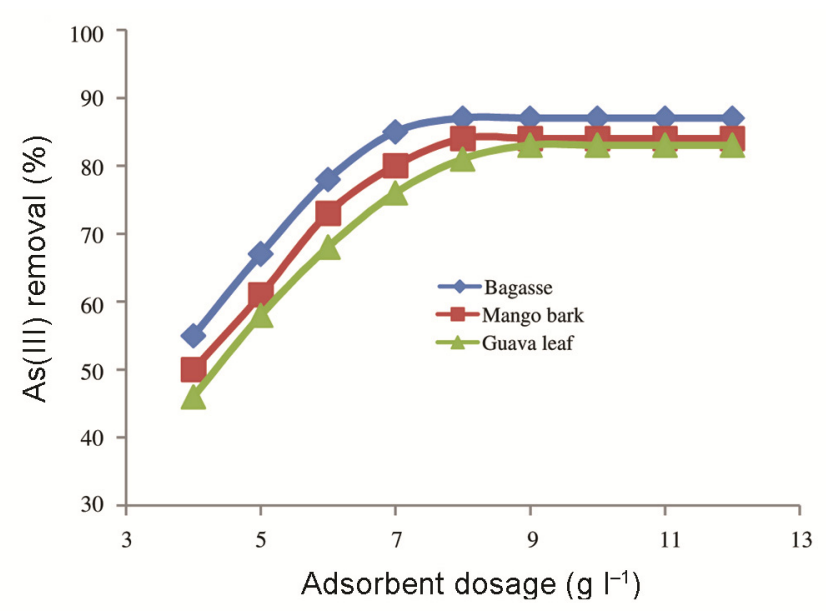

Figure 4. Effect of adsorbent dosage on As(III) adsorption.
Results shown in Figure 4 indicate that increased rate of removal of As(III) occurs only at certain adsorbent dosage and on further increase in dosage, adsorption rate remains the same due to the fact that all available adsorbate at particular concentration are attached at the active sites present in the solid adsorbent and therefore, further addition of adsorbent did not cause any significant enhancement in adsorption. Shipley et $a l^{33}$ studied adsorption of arsenic on magnetite nano-particles and observed that as the dosage of adsorbent was increased from $0.05 \mathrm{~g} \mathrm{l}^{-1}$ to $0.2 \mathrm{~g} \mathrm{l}^{-1}$, removal of $\mathrm{As}$ (III) also went up from $38.2 \mu \mathrm{g}^{-1}$ to $77.6 \mu \mathrm{g} \mathrm{l^{-1 }}$.

Significant adsorption of $\mathrm{As}(\mathrm{III})$ on the adsorbent surfaces of bagasse and mango bark was observed in the range of adsorbent dosage of 4 to $8 \mathrm{~g}$ and 4 to $9 \mathrm{~g}$ for guava leaf biomass (Figure 4). Further addition of adsorbent dosage remained ineffective for adsorption. Therefore, for the batch study, $8 \mathrm{~g}$ of dosage was considered as saturation dosage for bagasse and mango bark, and $9 \mathrm{~g}$ for guava leaf biomass as shown in Table 1.

\section{Adsorption isotherms}

Mass of As(III) adsorbed per unit mass of the adsorbent is defined as adsorption capacity of the adsorbent. Nature of adsorption can be explained by relating the adsorption capacity to equilibrium concentration of the adsorbate remaining in the solution using various isotherms ${ }^{34,35}$. Most common adsorption isotherms are Langmuir ${ }^{36}$, Freundlich $^{37}$, Temkin and Pyzhev ${ }^{38}$, Redlich-Peterson ${ }^{39}$, etc. In the present study, isotherms were plotted for each of the adsorbents using the experimental data (Figure 5). Equilibrium data of these isotherms have been analysed using the theories proposed by Freundlich, Langmuir, Temkin and Redlich-Peterson. Corresponding parameters calculated using these models are presented in Table 1.

Freundlich isotherm: Freundlich ${ }^{37}$ derived an empirical equation to describe non-ideal multilayer sorption on heterogeneous surface energy systems. Isotherms were defined by him over a limited range of concentrations and these can be shown by eq. (3). Linear form of Freundlich expression is presented in eq. (4).

$$
\begin{aligned}
& q_{e}=K_{f} C_{e}^{1 / n} \\
& \ln q_{e}=\ln K_{f}+\frac{1}{n} \ln C_{e}
\end{aligned}
$$

where $q_{e}$ is the solid phase sorbent concentration at equilibrium $\left(\mathrm{mg} \mathrm{g}^{-1}\right), C_{e}$ the aqueous phase sorbent concentration at equilibrium $\left(\mathrm{mg} \mathrm{l}^{-1}\right), n$ the Freundlich constant that represents the parameter characterizing QuasiGaussian energetic heterogeneity of the adsorption 
Table 1. Isotherm-parameters for adsorption of As(III) on the adsorbents

\begin{tabular}{|c|c|c|c|c|c|c|c|c|c|c|c|c|c|c|c|}
\hline \multirow{3}{*}{$\begin{array}{l}\text { Adsorbents } \\
\text { BG }\end{array}$} & \multicolumn{3}{|c|}{ Freundlich } & \multicolumn{5}{|c|}{ Langmuir } & \multicolumn{3}{|c|}{ Temkin } & \multicolumn{4}{|c|}{ Redlich-Peterson } \\
\hline & \multirow{2}{*}{$\begin{array}{c}\begin{array}{c}K_{\mathrm{f}} \\
\left(1 \mathrm{mg}^{-1}\right)\end{array} \\
0.265\end{array}$} & \multirow{2}{*}{$\begin{array}{c}1 / n \\
0.499\end{array}$} & \multirow{2}{*}{$\begin{array}{c}R^{2} \\
0.898\end{array}$} & \multirow{2}{*}{$\begin{array}{c}\begin{array}{c}q_{m} \\
\left(\mathrm{mg} \mathrm{g}^{-1}\right)\end{array} \\
1.35\end{array}$} & \multirow{2}{*}{$\begin{array}{c}\begin{array}{c}b \\
\left(1 \mathrm{mg}^{-1}\right)\end{array} \\
0.240\end{array}$} & \multirow{2}{*}{$\begin{array}{c}R^{2} \\
0.996\end{array}$} & \multicolumn{2}{|c|}{$\begin{array}{c}R_{L} \\
\text { Range }\end{array}$} & \multirow{2}{*}{$\begin{array}{c}\begin{array}{c}K_{T} \\
\left(1 \mathrm{mg}^{-1}\right)\end{array} \\
2.697\end{array}$} & \multirow{2}{*}{$\begin{array}{c}\begin{array}{c}b_{t} \\
\left(\mathrm{~kJ} \mathrm{~mol}^{-1}\right)\end{array} \\
0.278\end{array}$} & \multirow{2}{*}{$\begin{array}{c}R^{2} \\
0.962\end{array}$} & \multirow{2}{*}{$\begin{array}{r}\begin{array}{c}K_{\mathrm{RP}} \\
\left(\mathrm{mg} \mathrm{g}^{-1}\right)\end{array} \\
0.278\end{array}$} & \multirow{2}{*}{$\begin{array}{c}\begin{array}{c}b_{\mathrm{RP}} \\
\left(1 \mathrm{mg}^{-1}\right)\end{array} \\
0.105\end{array}$} & \multirow{2}{*}{$\begin{array}{l}\alpha_{\mathrm{RP}} \\
1.15\end{array}$} & \multirow{2}{*}{$\begin{array}{c}\mathrm{R}^{2} \\
0.999\end{array}$} \\
\hline & & & & & & & 0.029 & 0.294 & & & & & & & \\
\hline MB & 0.310 & 0.121 & 0.921 & 1.25 & 0.326 & 0.999 & 0.021 & 0.235 & 4.834 & 0.230 & 0.984 & 0.407 & 0.326 & 1.00 & 0.999 \\
\hline GL & 0.257 & 0.423 & 0.895 & 1.05 & 0.327 & 0.998 & 0.021 & 0.234 & 4.262 & 0.201 & 0.969 & 0.257 & 0.158 & 1.11 & 0.999 \\
\hline
\end{tabular}

BG, Bagasse; MB, Mango bark and GL, Guava leaf biomass.

Table 2. Kinetic parameters for adsorption of As(III) on the adsorbents

\begin{tabular}{|c|c|c|c|c|c|c|c|c|c|c|c|c|}
\hline \multirow{2}{*}{ Adsorbents } & \multirow{2}{*}{\multicolumn{4}{|c|}{ Pseudo-first-order }} & \multicolumn{8}{|c|}{ Pseudo-second-order } \\
\hline & & & & & \multicolumn{4}{|c|}{ Type 1} & \multicolumn{4}{|c|}{ Type 2} \\
\hline BG & 1.088 & $11.66 \times 10^{-3}$ & 0.771 & 6.983 & $53.20 \times 10^{-4}$ & 0.009 & 0.987 & 1.267 & $11.41 \times 10^{-3}$ & 0.014 & 0.923 & 1.099 \\
\hline MB & 1.050 & $11.55 \times 10^{-3}$ & 0.801 & 5.062 & $80.32 \times 10^{-4}$ & 0.011 & 0.994 & 1.117 & $15.69 \times 10^{-3}$ & 0.018 & 0.916 & 1.060 \\
\hline GL & 0.922 & $11.50 \times 10^{-3}$ & 0.800 & 5.212 & $69.63 \times 10^{-4}$ & 0.008 & 0.987 & 1.060 & $15.11 \times 10^{-3}$ & 0.013 & 0.917 & 0.928 \\
\hline
\end{tabular}

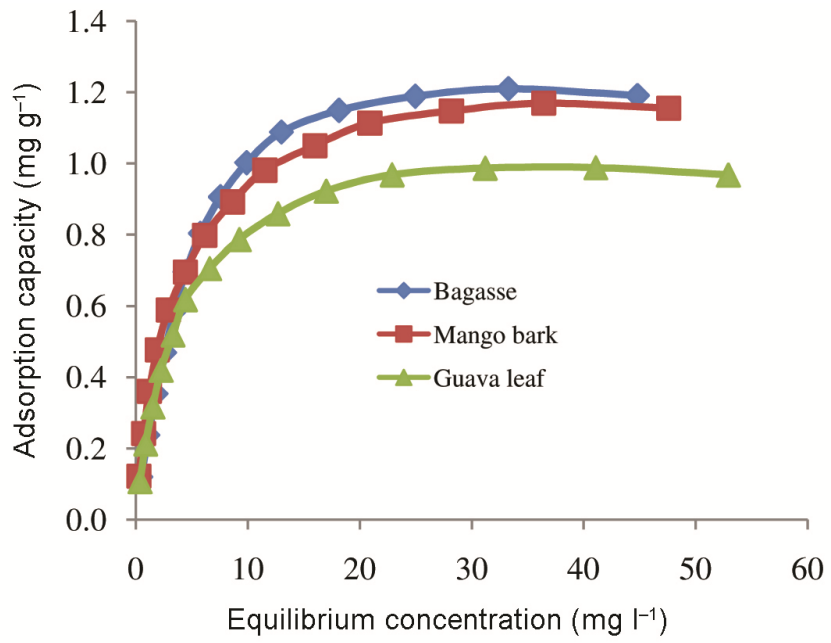

Figure 5. Adsorption isotherms for As(III) adsorption.

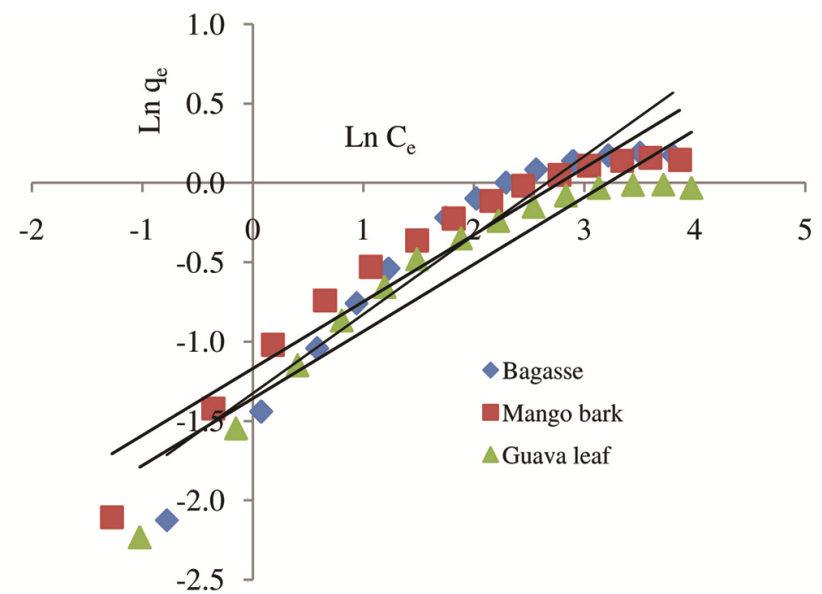

Figure 6. Freundlich isotherms for As(III) adsorption. surface $^{40-42}$ and $K_{f}$ is another Freundlich constant, indicative of the relative adsorption capacities of the adsorbents $\left(1 \mathrm{~g}^{-1}\right)$.

Freundlich isotherm was tested to understand the adsorption intensity of As(III) on the adsorbent surfaces of bagasse, mango bark and guava leaf biomass. The experimental data were plotted logarithmically (Figure 6), applying the linear Freundlich isotherm eq. (4). The linear Freundlich isotherm constants for As(III) adsorption are presented in Table 2.

Langmuir isotherm: Langmuir described adsorption as a result of formation of an ionic or covalent bond between adsorbent and adsorbate molecules and defined fractional coverage $(\theta)$ in the form eq. (5).

$$
\theta=\frac{q_{e}}{q_{m}}=\frac{b C_{e}}{1+b C_{e}}
$$

where $b$ is a parameter for apparent energy of sorption, defined as, $b=\left(\mathrm{k}_{\mathrm{a}} / \mathrm{k}_{\mathrm{d}}\right), \quad \mathrm{k}_{\mathrm{a}}$ and $\mathrm{k}_{\mathrm{d}}$ are constants for adsorption and desorption respectively, $q_{m}$ the maximum quantity of $\mathrm{As}$ (III) required to form a single monolayer on unit mass of adsorbent, $q_{e}$ the sorbate concentration on solid phase at equilibrium $\left(\mathrm{mg} \mathrm{g}^{-1}\right)$ and $C_{e}$ is the aqueous phase sorbate concentration at equilibrium $\left(\mathrm{mg} \mathrm{l}^{-1}\right)$. Linearization of eq. (5) yields eq. (6) and can be expressed as Langmuir isotherm, from which values of the constant $b$ and $q_{m}$ can be determined from the slope and intercept by plotting $C_{e} / q_{e}$ versus $C_{e}$ (refs 43,44$)$

$$
\frac{C_{e}}{q_{e}}=\frac{1}{b q_{m}}+\frac{1}{q_{m}}\left(C_{e}\right)
$$


Langmuir isotherm has been considered to estimate the maximum adsorption capacity corresponding to the monolayer coverage on the adsorbents surfaces. Plots of specific sorption $\left(C_{e} / q_{e}\right)$ against $C_{e}$ for these adsorbent are shown in Figure 7 and the isotherm parameters, $q_{m}, b$ and $R^{2}$ are presented in Table 1 . The sorption capacity, $q_{m}$ has higher value for bagasse $\left(1.346 \mathrm{mg} \mathrm{g}^{-1}\right)$ compared to the values for mango bark $\left(1.249 \mathrm{mg} \mathrm{g}^{-1}\right)$ and guava leaf biomass $\left(1.052 \mathrm{mg} \mathrm{g}^{-1}\right)$. From the results, it can be understood that bagasse has more capacity to adsorb As(III) than that of mango bark and guava leaf biomass. The adsorption coefficient, $b$ for As(III) on guava leaf biomass $\left(0.3271 \mathrm{mg}^{-1}\right)$ was greater than that of mango leaf $\left(0.3261 \mathrm{mg}^{-1}\right)$ and bagasse $\left(0.2401 \mathrm{mg}^{-1}\right)$ (Table 1$)$. It indicated that, the effectiveness of As(III) adsorption on the adsorbents surface was bagasse $>$ mango bark $>$ guava leaf biomass. The value of $R^{2}$ for As(III) adsorption on the surface of mango bark (0.999) was greater than guava leaf biomass (0.998) and bagasse (0.996; Figure 7). It leads to a conclusion that adsorption on guava leaf biomass fits better than that on bagasse and mango bark.

Furthermore, appropriateness of As(III) adsorption on the adsorbents was tested using features of Langmuir isotherm, expressed in terms of a non-dimensional constant, called separation factor $R_{\mathrm{L}}$ and defined by eq. $(7)^{40}$.

$$
R_{L}=\frac{1}{1+b C_{o}}
$$

where $C_{o}\left(\mathrm{mg} \mathrm{l}^{-1}\right)$ is the initial concentration of arsenite solution and $b\left(\mathrm{mg}^{-1}\right)$ is Langmuir isotherm constant. Value of $R_{L}$ should be between 0 and 1 for favourable adsorption, $R_{L}>1$ represents unfavourable conditions. $R_{L}=1$ indicates linear adsorption, while adsorption process is irreversible, if $R_{L}=0 . R_{L}$ value for adsorption of arsenic on the surface of the adsorbents was found to be in the range 0.029 to 0.294 (bagasse), 0.021 to 0.235 (mango bark) and 0.021 to 0.234 (guava leaf biomass) under different conditions. Values of the separation parameters for all adsorbents being less than unity indicate that all adsorbents could provide favourable conditions (to different degrees) for adsorption of As(III). The smaller $R_{L}$ value indicates a highly favourable adsorption and $R_{L}$ values of guava leaf biomass $>$ mango bark $>$ bagasse.

Temkin isotherm: Temkin isotherm is represented by eq. (8) and on linearization, it is given by eq. (9).

$$
\begin{aligned}
& q_{e}=\frac{\mathrm{R} T}{\mathrm{~B}_{\mathrm{t}}} \ln \left(\mathrm{K}_{\mathrm{T}} C_{e}\right) \\
& q_{e}=\mathrm{B}_{\mathrm{t}} \ln \mathrm{K}_{\mathrm{T}}+\mathrm{B}_{\mathrm{t}} \ln C_{e}
\end{aligned}
$$

where $T$ is the absolute temperature $(\mathrm{K}), \mathrm{R}$ the universal gas constant $\left(8.314 \mathrm{~J} \mathrm{~mol}^{-1} \mathrm{~K}^{-1}\right), \mathrm{K}_{\mathrm{T}}$ the equilibrium binding constant $\left(\mathrm{mg}^{-1}\right)$ and $\mathrm{B}_{\mathrm{t}}$ is the Temkin constant related to the heat of adsorption $\left(\mathrm{kJ} \mathrm{mol}^{-1}\right)$. Temkin isotherm was also plotted to understand adsorption phenomenon of these adsorbents. Temkin isotherm plots for these three adsorbents are presented in Figure 8 and the isotherm parameters in Table 1. Values of Temkin adsorption potential, $\mathrm{K}_{\mathrm{T}}$, for mango bark, guava leaf biomass and bagasse were found to be $4.834 \mathrm{l} \mathrm{mg}^{-1}$, $4.262 \mathrm{l} \mathrm{mg}^{-1}$ and $2.6971 \mathrm{mg}^{-1}$ respectively. This indicates lowest adsorbent-As(III) potential of bagasse and highest for mango bark among the adsorbents. Temkin constant, $\mathrm{B}_{\mathrm{t}}$, related to heat of sorption for As(III) adsorption on the adsorbents and higher value is reported for bagasse $\left(0.278 \mathrm{~kJ} \mathrm{~mol}^{-1}\right)$ rather than mango bark $\left(0.230 \mathrm{~kJ} \mathrm{~mol}^{-1}\right)$ and guava leaf biomass $\left(0.201 \mathrm{~kJ} \mathrm{~mol}^{-1}\right)$. It has been reported $^{45}$ that the typical range of bonding energy for ion-exchange mechanism is 8 to $16 \mathrm{~kJ} \mathrm{~mol}^{-1}$.

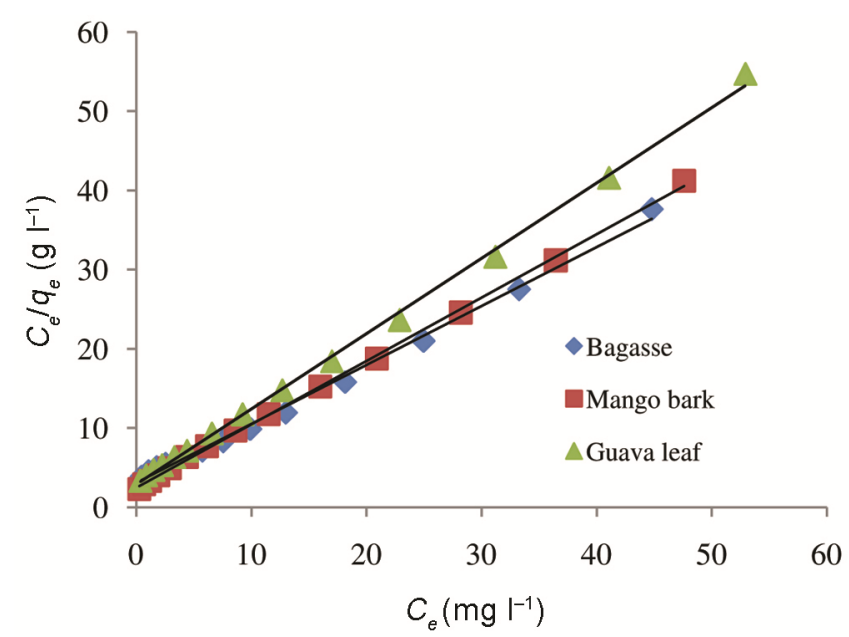

Figure 7. Langmuir isotherms for As(III) adsorption.

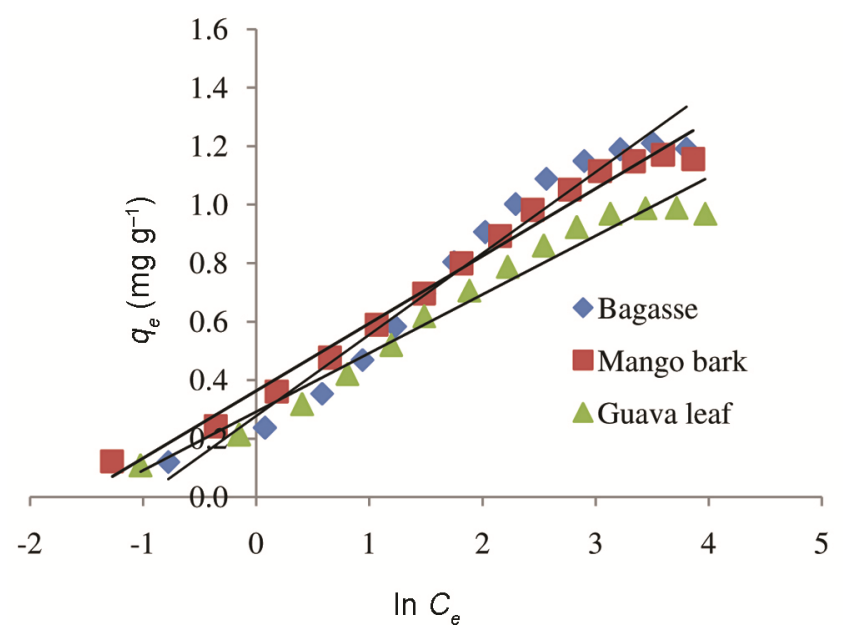

Figure 8. Temkin isotherms for As(III) adsorption. 
Redlich-Peterson isotherm: Redlich and Peterson ${ }^{39}$ suggested an isotherm eq. (10) having three adsorption parameters in 1959, unanimously called Redlich-Peterson (R-P) isotherm. This equation amends inaccuracies of two parameter Langmuir and Freundlich isotherms equation in adsorption systems and can be written as eq. (10) and on further linearization as eq. (11).

$$
\begin{aligned}
& q_{e}=\frac{\left(q_{m} b_{\mathrm{RP}}\right) C_{e}}{1+b_{\mathrm{RP}} C_{e}^{\alpha_{\mathrm{RP}}}}=\frac{\left(K_{\mathrm{RP}}\right) C_{e}}{1+b_{\mathrm{RP}} C_{e}^{\alpha_{\mathrm{RP}}}} \\
& \frac{C_{e}}{q_{e}}=\frac{1}{K_{\mathrm{RP}}}+\frac{b_{\mathrm{RP}}}{K_{\mathrm{RP}}} C_{e}^{\alpha_{\mathrm{RP}}}
\end{aligned}
$$

where $K_{\mathrm{RP}}\left(1 \mathrm{~g}^{-1}\right), b_{\mathrm{RP}}\left(1 \mathrm{~m}^{-1} \mathrm{~mol}^{-1}\right)$ and $\alpha_{\mathrm{RP}}$ are RedlichPeterson constants and $q_{m}$ is the maximum quantity of adsorbate required to form a single monolayer on unit mass of adsorbent. Redlich-Peterson isotherm constants can be predicted from the plot between $C_{e} / q_{e}$ versus $C_{e}^{\alpha_{\mathrm{RP}}}$. It has been experimentally proven that when $\alpha_{\mathrm{RP}}=1$, Redlich-Peterson isotherm reduces into Langmuir isotherm; similarly when intercept of eq. (11) is closest to zero, it reduces to Freundlich isotherm ${ }^{46}$.

Linearized form of Redlich-Peterson isotherm equation contains three unknown parameters $K_{\mathrm{RP}}, \mathrm{b}_{\mathrm{RP}}$ and $\alpha_{\mathrm{RP}}$ and hence it is not possible to determine. Therefore, a minimization procedure was adopted to maximize $R^{2}$, between the theoretical data for $q_{e}$ predicted from the linearized form of Redlich-Peterson isotherm equation and the experimental data. Trial and error method was adopted to select constant, $\alpha_{\mathrm{RP}}$ through optimization of $R^{2}$. RedlichPeterson isotherm plot for the As(III) adsorption on all three adsorbents are presented in Figure 9 and the isotherm parameters are given in Table 1. The value of $\alpha_{\mathrm{RP}}$ greater than unity shows the steeper slope in Langmuir isotherm equation. Higher $R^{2}$ values for Redlich-Peterson were obtained, which indicates that the experimental equilibrium data is more consistent with Redlich-Peterson isotherm equation. This was expected, because a degree of heterogeneity $\left(\alpha_{\mathrm{RP}}\right)$ is included and this equation can be used successfully at high solute concentrations ${ }^{46}$.

Comparison of isotherm models: Adsorption isotherms were analysed using the postulates made by Freundlich, Langmuir, Temkin and Redlich-Peterson and ultimate capacity of adsorbents to adsorb As(III) was computed. Quasi-Gaussian energetic heterogeneity of the adsorption surface obtained from Freundlich isotherm indicates the better adsorption of As(III) on the surface of bagasse and least adsorption on mango bark. However, the value of Freundlich constant $\mathrm{K}_{\mathrm{f}}$ shows that bagasse has maximum tendency to adsorb ions followed by mango bark and guava leaf biomass. Single layer adsorption of ions on guava leaf biomass and bagasse surface was reported by
Langmuir isotherm. The parameter $1 / n$ measures adsorption intensity of $\mathrm{As}$ (III) on the adsorbents. Higher value of $1 / n$ on bagasse (0.499) compared to guava leaf biomass (0.432) and mango bark (0.121), indicates preferential sorption of As(III) on bagasse than on guava leaf biomass or mango bark. It also represents the ability of the adsorbents to remove As(III) from solution even at high concentrations. Values of ultimate adsorption capacity $\mathrm{K}_{\mathrm{f}}\left(\mathrm{l} \mathrm{g}^{-1}\right)$ of the adsorbents were calculated from the linear regression equation (Figure 6 ). The $K_{f}$ value of mango bark $\left(0.310 \mathrm{~g} \mathrm{~g}^{-1}\right)$ is more than that of bagasse $\left(0.265 \mathrm{lg}^{-1}\right)$ and guava leaf biomass $\left(0.257 \mathrm{lg}^{-1}\right)$, suggesting and confirming that mango bark has greater adsorption tendency to adsorb arsenic than the other two adsorbents. The lower value of coefficient of determination $\left(R^{2}\right)$ for As(III) adsorption on surface of guava leaf biomass $(0.895)$ and bagasse $(0.898)$ indicates the possibility of single layer adsorption, however higher $R^{2}$ for mango bark (0.921) indicates multilayer adsorption of arsenite species.

Separation factor observed for each adsorbent indicates favourable adsorption on adsorbent. Value of $R^{2}(>0.900)$ calculated for each adsorbent also indicates the applicability of Langmuir hypothesis, i.e. monolayer adsorption and adsorption sites will be independent of the occupation of neighbouring sites with the accommodation of only one adsorbed atom on each adsorption site in the form of complexes of reactive functional groups present on the surface of the adsorbent. Quantity of As(III) required to form a single monolayer on unit mass of adsorbent calculated using Langmuir isotherm indicates that bagasse has higher adsorption capacity $\left(1.346 \mathrm{mg} \mathrm{g}^{-1}\right)$ compared to mango bark (1.249 $\left.\mathrm{mg} \mathrm{g}^{-1}\right)$ and guava leaf biomass $\left(1.052 \mathrm{mg} \mathrm{g}^{-1}\right)$. Apparent energy of sorption for adsorbent showed that adsorption on guava leaf biomass is more effective compared to mango bark and bagasse. Equilibrium binding constant $\left(1 \mathrm{mg}^{-1}\right)$ calculated from Temkin isotherm showed that bagasse has least potential to

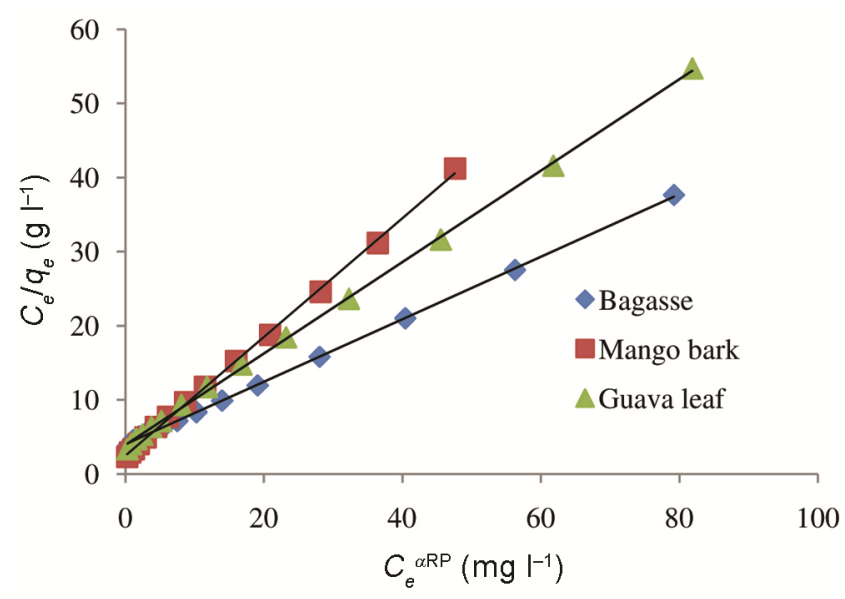

Figure 9. Redlich-Peterson isotherms for As(III) adsorption. 
adsorb As(III). Heat of sorption was observed for bagasse as $0.278 \mathrm{~kJ} \mathrm{~mol}^{-1}$, mango bark as $0.230 \mathrm{~kJ} \mathrm{~mol}^{-1}$ and guava leaf biomass as $0.201 \mathrm{~kJ} \mathrm{~mol}^{-1}$. Relatively lower values in this study indicate a weak interaction between sorbate and sorbent for ion-exchange mechanism. Introduction of heterogeneity factor in Langmuir isotherm gave more appropriate isotherm to describe the adsorption of As(III). Higher values of $R^{2}(>0.999)$ for RedlichPeterson and Langmuir showed that both isotherms are more applicable and appropriate in describing the experimental data and confirm the monolayer adsorption of As(III) on the solid surface of the adsorbents. Uptake rates of As(III) on adsorbent surfaces was further studied using various models involving pseudo-first-order, pseudo-second-order, Elovich and intra-particle diffusion. Kinetic parameters were also investigated to comprehend the pattern of uptake.

\section{Adsorption kinetics}

Most of the sorption/desorption processes of various solid phases are time-dependent. Knowledge of these kinetic processes is essential to understand the solute uptake rate and evidently this rate controls the residence time of adsorbate uptake at solid-solution interface ${ }^{45}$. The dynamic interactions of As(III) adsorption on the adsorbents of bagasse, mango bark and guava leaf biomass were analysed to predict their fate with time using pseudofirst-order, pseudo-second-order, Elovitch and intraparticle diffusion kinetics. The conformity between experimental data and model predicted values were expressed by $R^{2}$.

Pseudo-first-order kinetic model: Pseudo-first-order equation or Lagergren's kinetic equation for the adsorption of adsorbate from aqueous solution is generally expressed by eq. (12) and after integration and applying boundary conditions $t=0$ to $t=t$ and $q=0$ to $q=q$, it is represented by eq. (13).

$$
\begin{aligned}
& \frac{\mathrm{d} q}{\mathrm{~d} t}=k_{1}\left(q_{e}-q\right) \\
& \ln \left(q_{e}-q\right)=\ln \left(q_{e}\right)-k_{1} t
\end{aligned}
$$

where $q$ and $q_{e}$ are the amounts of As(III) adsorbed per unit mass of adsorbent, $\left(\mathrm{mg} \mathrm{g}^{-1}\right)$ at time $t$ and equilibrium respectively; $k_{1}$ is the pseudo-first-order rate constant, $\left(1 \mathrm{~min}^{-1}\right)$ and $t$ is the contact time (min). Pseudo-firstorder kinetic model was chosen to estimate the As(III) adsorption rate constant from the experimental batch study.

The plot of $\ln \left(q_{e}-q\right)$ versus $t$ shown in Figure 10 was used to find the rate constant and is reported in Table 2 . Almost the same adsorption rate constant was observed for each adsorbent. Bagasse has slightly higher rate con- stant as $11.66 \times 10^{-3} \mathrm{~min}^{-1}$ compared to $11.55 \times 10^{-3} \mathrm{~min}^{-1}$ for guava leaf biomass and $11.50 \times 10^{-3} \mathrm{~min}^{-1}$ for mango bark. Lower value of $R^{2}$ was observed for all the adsorbents which indicates that rate of adsorption of As(III) on adsorbent surface is not in proportion to $k_{1}\left(q_{e}-q\right)$ and does not represent true number of available sites for further adsorption on the adsorbent's surface. The possibility of As(III) present in aqueous solution being adsorbed at saturated condition was found to be $6.983 \mathrm{mg} \mathrm{g}^{-1}$ (bagasse) compared to the experimental value of $1.088 \mathrm{mg} \mathrm{g}^{-1}$ (Table 2), $5.062 \mathrm{mg} \mathrm{g}^{-1}$ (mango bark) against true experimental value of $1.050 \mathrm{mg} \mathrm{g}^{-1}$ and $5.212 \mathrm{mg} \mathrm{g}^{-1}$ (guava leaf biomass) against $0.922 \mathrm{mg} \mathrm{g}^{-1}$. It may be due to the fact that $\ln \left(q_{e}\right)$ is an adjustable parameter and often found to be not equal to the intercept of the plot $\ln \left(q_{e}-q\right)$ versus $t$ (refs 47, 48). All these indicate that first-order-kinetic is inadequate in representing good account of the adsorption kinetics of As(III).

Pseudo-second-order kinetic model: Pseudo-secondorder adsorption equation is expressed by eq. (14). On further integrating and applying boundary conditions, $t=0$ to $t=t$ and $q=0$ to $q=q$, it is linearized and presented in eqs (16) and (17) as type 1 kinetic and type 2 kinetic by Markandeya et al. $^{49}$. Pseudo-second-order rate constant, $k_{2}\left(\mathrm{~g} \mathrm{mg}^{-1} \mathrm{~min}^{-1}\right)$ and ultimate adsorption capacity of adsorbent, $q_{e}\left(\mathrm{mg} \mathrm{g}^{-1}\right)$ were obtained from the plot of $t / q$ versus $t$ (type 1; Figure 11) and $1 / q$ versus $1 / t$ (type 2; Figure 12) respectively and are reported in Table 2.

$\frac{\mathrm{d} q}{\mathrm{~d} t}=k_{2}\left(q_{e}-q\right)^{2}$

$\frac{1}{q_{e}-q}=\frac{1}{q_{e}}+k_{2} t$

Type 1: $\left(\frac{t}{q}\right)=\frac{1}{k_{2} q_{e}^{2}}+\frac{1}{q_{e}}(t)$

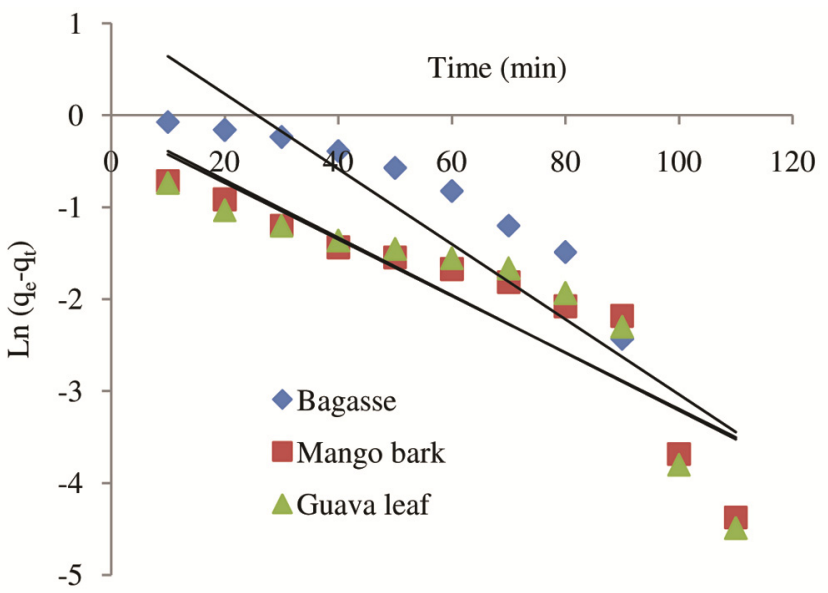

Figure 10. Pseudo-first-order plot for kinetics of As(III) adsorption. 


$$
\text { Type 2: }\left(\frac{1}{q}\right)=\frac{1}{q_{e}}+\left(\frac{1}{k_{2} q_{e}^{2}}\right) \frac{1}{t}
$$

Markandeya et $a l .{ }^{50}$ have defined another adsorption rate parameter, $h\left(\mathrm{mg} \mathrm{g}^{-1} \mathrm{~min}^{-1}\right)$ by eq. (16) to study the initial adsorption rate as eq. (18).

$$
h=k_{2} q_{e}^{2}
$$

Experimental observations presented in Figures 10 and 13 indicated three stages of adsorption. Highest initial adsorption rate was observed for adsorption on mango bark for $0.011 \mathrm{mg} \mathrm{g}^{-1} \mathrm{~min}^{-1}$ compared to bagasse $\left(0.009 \mathrm{mg} \mathrm{g}^{-1}\right.$ $\left.\mathrm{min}^{-1}\right)$ and guava leaf biomass $\left(0.008 \mathrm{mg} \mathrm{g}^{-1} \mathrm{~min}^{-1}\right)$ for type 1 kinetic. Similarly the trend for $h$ was also reported for type 2 kinetic and is presented in Table 2. It indicates that at the beginning, As(III) uptake on adsorbents will be more for mango bark followed by bagasse and guava leaf biomass. This As(III) uptake on adsorbent surface is from the diffusion of metal ion species on the boundary of adsorbent mainly due to their concentration gradient resulting with high uptake rate. However, adsorption will go on decreasing as concentration gradient decreases.

The second and third stages of adsorption are due to the formation of inner-sphere mono-dentate and bi-dentate surface complexes that depend upon the composition and texture of the adsorbent surface. These inner sphere complexes are covalent linkages between As(III) and reactive surface functional groups present in the adsorbents $^{31}$.

Pseudo-second-order adsorption rate, $k_{2}$ was more for mango bark $\left(80.32 \times 10^{-5} \mathrm{~g} \mathrm{mg}^{-1} \mathrm{~min}^{-1}\right)$ followed by guava leaf biomass $\left(69.63 \times 10^{-5} \mathrm{~g} \mathrm{mg}^{-1} \mathrm{~min}^{-1}\right)$ and bagasse $\left(53.21 \times 10^{-5} \mathrm{~g} \mathrm{mg}^{-1} \mathrm{~min}^{-1}\right)$. Adsorption capacity predicted by type 2 kinetic is closer to its experiment

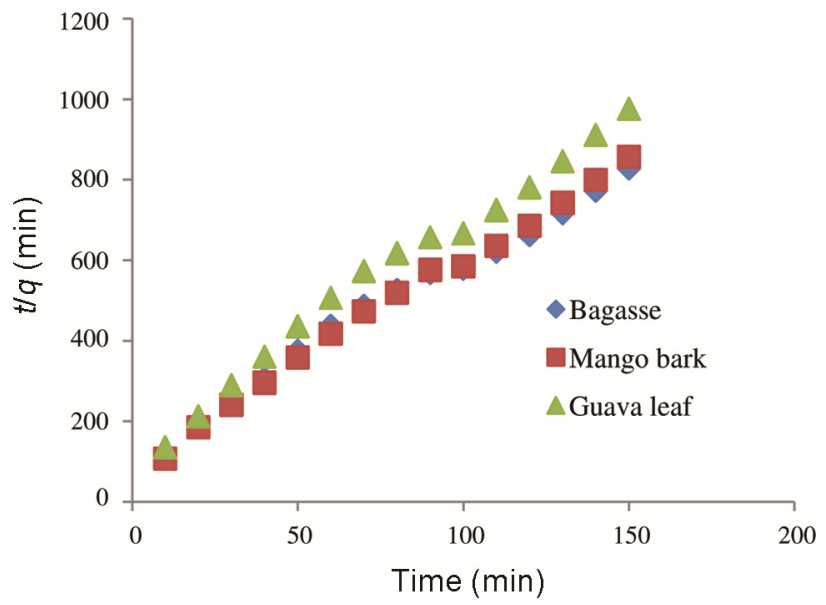

Figure 11. Pseudo-second-order plot (type 1) for kinetics of As(III) adsorption. value compared to type 1 . It indicates that adsorption sites for As(III) uptake on each adsorbent can be represented by $k_{2}\left(q_{e}-q\right)^{2}$. This capacity for metal complexation depends upon the affinity and specificity including physico-chemical nature of functional groups present in adsorbents ${ }^{17}$. Higher value of $R^{2}$ was observed for mango bark (0.994) and the same value for bagasse and guava leaf biomass $(0.987)$ as reported by type 1 kinetic. Type 2 kinetic also reported very little difference in $R^{2}$ values for each adsorbent. This higher value of $R^{2}$ $(>0.90)$ makes the second order kinetic applicable for adsorption of As(III) on each adsorbent.

Elovich kinetic model: Elovich kinetic equation is generally expressed by eq. (19) as given below.

$$
\frac{\mathrm{d} q}{\mathrm{~d} t}=\alpha \mathrm{e}^{(-\beta q)}
$$

where $\alpha$ is the initial adsorption rate $\left(\mathrm{mg} \mathrm{g}^{-1} \mathrm{~min}^{-1}\right)$ and $\beta$ is the desorption constant $\left(\mathrm{g} \mathrm{mg}^{-1}\right)$ during any experiment. Simplifying eq. (19) proposed by Chien and Clay$\operatorname{ton}^{51}$ and applying the boundary conditions $t=0$ to $t=t$ and $q=0$ to $q=q$, it is represented by eq. (20).

$$
q=\frac{1}{\beta} \ln (\alpha \beta)+\frac{1}{\beta} \ln (t)
$$

Desorption constant and initial adsorption rate were calculated from the slope and intercept of plot of $q$ versus $\ln (t)$ (Figure 13) and reported in Table 3. Higher initial rate for mango bark $\left(0.049 \mathrm{mg} \mathrm{g}^{-1} \mathrm{~min}^{-1}\right)$ was observed compared to guava leaf biomass $\left(0.028 \mathrm{mg} \mathrm{g}^{-1} \mathrm{~min}^{-1}\right)$ and bagasse $\left(0.026 \mathrm{mg} \mathrm{g}^{-1} \mathrm{~min}^{-1}\right)$. It shows that As(III) has higher affinity to form inner-sphere mono-dentate surface complexes. Desorption constant was reported maximum for guava leaf biomass $\left(5.257 \mathrm{~g} \mathrm{mg}^{-1}\right)$ followed by mango

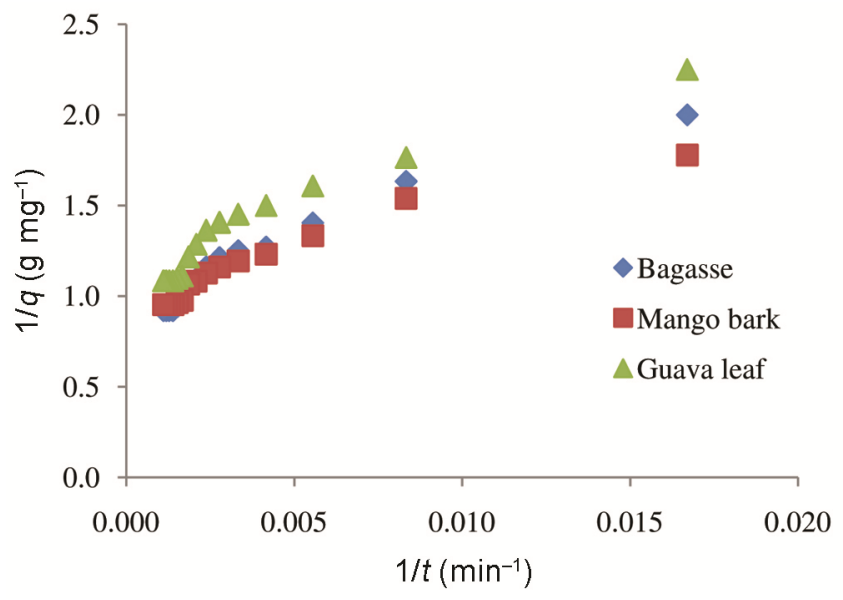

Figure 12. Pseudo-second-order plot (type 2) for kinetics of As(III) adsorption. 
Table 3. Kinetic parameters for adsorption of As(III) on the adsorbents

\begin{tabular}{|c|c|c|c|c|c|c|}
\hline \multirow[b]{2}{*}{ Adsorbent } & \multicolumn{3}{|c|}{ Elovich model } & \multicolumn{3}{|c|}{ Intra-particle diffusion model } \\
\hline & $A\left(\mathrm{mg} \mathrm{g}^{-1} \mathrm{~min}\right)$ & $\beta\left(\mathrm{g} \mathrm{mg}^{-1}\right)$ & $R^{2}$ & $\mathrm{k}_{\mathrm{id}}\left(\min ^{-1}\right)$ & $A\left(\% \min ^{-1}\right)$ & $R^{2}$ \\
\hline BG & 0.026 & 4.228 & 0.966 & 11.87 & 0.298 & 0.986 \\
\hline MB & 0.049 & 5.086 & 0.977 & 16.77 & 0.242 & 0.986 \\
\hline GL & 0.028 & 5.257 & 0.957 & 13.16 & 0.275 & 0.978 \\
\hline
\end{tabular}

$\mathrm{BG}=$ bagasse, $\mathrm{MB}=$ mango bark and $\mathrm{GL}=$ guava leaf biomass.

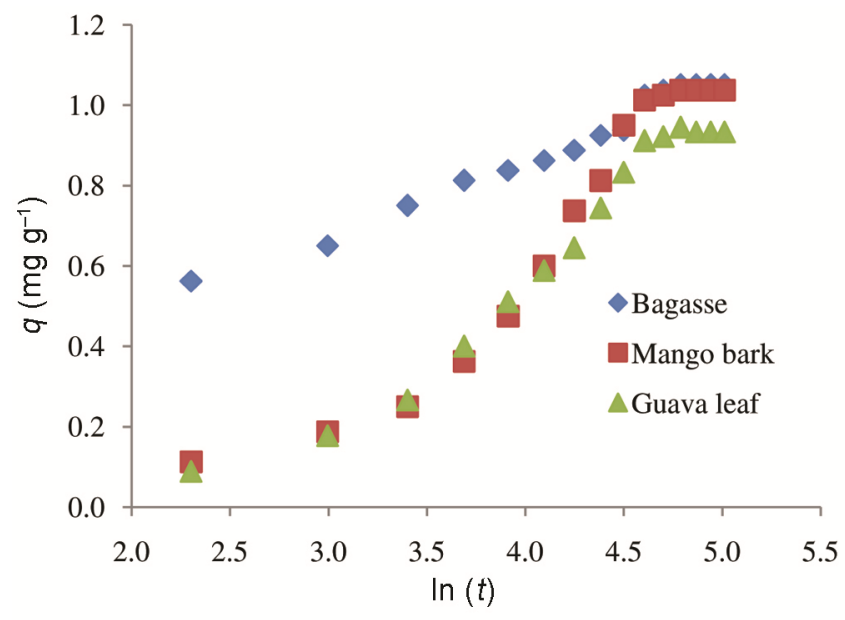

Figure 13. Elovich plots for the kinetics of As(III) adsorption.

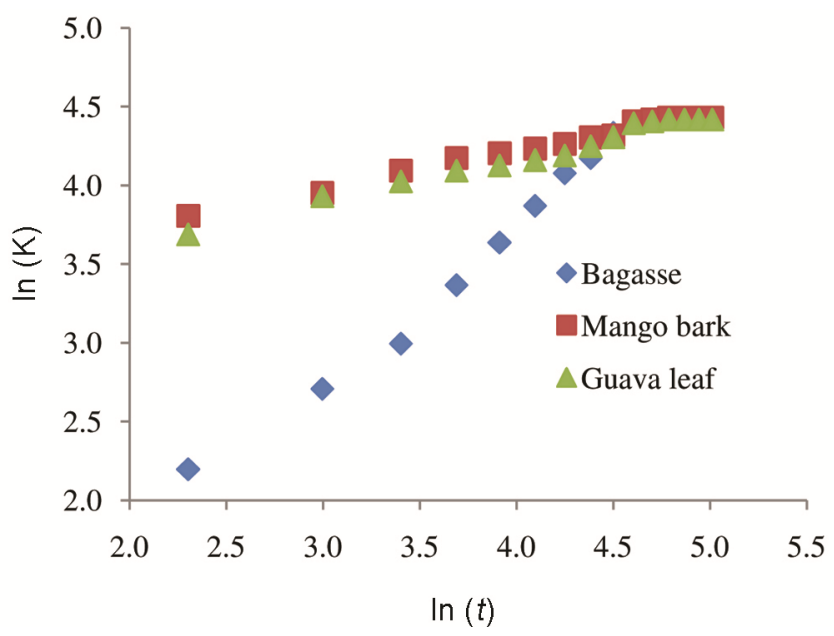

Figure 14. Intra-particle plots for the kinetics of As(III) adsorption.

bark $\left(5.086 \mathrm{~g} \mathrm{mg}^{-1}\right)$ and bagasse $\left(4.228 \mathrm{~g} \mathrm{mg}^{-1}\right)$. It shows that bagasse has strong covalent linkage between As(III) and reactive functional group present in the adsorbents compared to mango bark and guava leaf biomass. Higher values of $R^{2}(>0.90)$ were observed for all adsorbents, indicating applicability of the model.

Intra-particle diffusion model: Intra-particle model defined by Weber and Morris ${ }^{52}$ followed by linearization is represented in eqs (21) and (22) respectively ${ }^{53}$.

$$
\begin{aligned}
& R=k_{\text {id }}(t)^{a} \\
& \ln (R)=\ln \left(k_{\mathrm{id}}\right)+a \ln (t)
\end{aligned}
$$

where $R$ is the percentage As(III) adsorbed, $t$ is the contact time ( $\mathrm{min}$ ), $a$ diffusion factor for the adsorption and depicts the adsorption mechanism and $k_{\text {id }}$ is the intraparticle diffusion rate constant $\left(\mathrm{min}^{-1}\right)$, i.e. percentage As(III) adsorbed per unit time. Diffusion factor and rate constant were determined from the slope and intercept of the plot of $\ln (R)$ versus $\ln (t)$ (Figure 14) and reported in Table 3.

Data presented in Table 2, $5.062 \mathrm{mg} \mathrm{g}^{-1}$ shows maximum diffusion rate for mango bark followed by guava leaf biomass and bagasse. But diffusion factor, $a$ is lowest for mango bark compared to guava leaf biomass and bagasse. Higher values of $k_{\text {id }}$ demonstrate an enrichment in the rate of adsorption, whereas large $a$ values illustrate a better adsorption mechanism, which is related to an improved bonding between adsorbate and adsorbent species $^{54}$.

Comparison of kinetic models: Kinetic studies for the adsorption of As(III) on adsorbents of bagasse, mango bark and guava leaf biomass were conducted using pseudo-first-order, pseudo-second-order, Elovich and intraparticle diffusion models which are shown in Figures 1014 and kinetic parameters are reported in Tables 2 and 3. Higher value of $R^{2}$ and perfect straight lines were obtained for pseudo-second-order kinetic plot of $(t / q)$ versus $(t)$ for adsorption of As(III) on all adsorbents, indicating that pseudo-first-order adsorption reaction is not adequate and pseudo-second-order kinetic model can approximate a good account of adsorption kinetics. Initial rate constant obtained from all kinetic models shows that molecules of mango bark have higher tendency to form mono and bidentate complexes giving more affinity between As(III) and adsorbent surface. However, results of intra-particle diffusion and Elovich kinetic model indicate that mango bark has lower bonding linkage of As(III) on adsorbent surface after $2-3 \mathrm{~h}$ of adsorption, indicating comparatively poor adsorption capability. Results of these models also indicate that adsorbent of bagasse has more adsorption ability followed by guava leaf biomass and mango bark. 


\section{Conclusion}

Extensive laboratory investigations were conducted to evaluate the adsorptive capability of low cost adsorbents prepared from materials of bagasse, mango bark and guava leaf biomass for adsorption of As(III). The results indicated that these adsorbents have the capacities to treat arsenic contaminated water. Kinetic parameters calculated from Elovich and intra-particle models indicate that bagasse has better adsorption capacity followed by guava leaf biomass and mango bark. Contact time, adsorbent dosage and $\mathrm{pH}$ were observed to be amongst the most effective controlling parameters for As(III) adsorption. Adsorbents prepared from bagasse, mango bark and guava leaf biomass have the maximum removal values of As(III) at 7.5, 6.5 and 6.0 respectively. Pseudo-secondorder kinetics for adsorption of As(III) was followed in the three stages. First stage of adsorption was rapid diffusion of As(III) from aqueous solution to boundary of adsorbent pores followed by arrangement of adsorption sites through the formation of inner spherical mono-dentate complexes and finally, formation of bi-dentate complexes within a very short duration. Monolayer adsorption of As(III) on the adsorbents was confirmed by Freundlich, Langmuir and Redlich-Peterson models. Adsorption capacity on surface of bagasse obtained from Langmuir isotherms was the highest for bagasse as $1.35 \mathrm{mg} \mathrm{g}^{-1}$ compared to mango bark $\left(1.25 \mathrm{mg} \mathrm{g}^{-1}\right)$ and guava leaf biomass $\left(1.05 \mathrm{mg} \mathrm{g}^{-1}\right)$.

Conflict of interest: There is no conflict of interest in the present study.

1. Shukla, N. K., Markandeya and Shukla, V. K., Arsenic and physico-chemical calamity in the ground water samples of Ballia district, Uttar Pradesh, India. Iranica J. Energy Environ., 2015, 6(4), 328-333.

2. Choong, Y. S. T., Chuah, G. T., Robia, H. Y., Koay, L. F. G. and Azni, I., Arsenic toxicity, health hazards and removal techniques from water: an overview. Desalination, 2007, 217, 139-166.

3. Shevade, S. and Ford, R., Use of synthetic zeolites for arsenate removal from pollutant water. Water Res., 2004, 38, $3197-$ 3204.

4. Mandal, B. K. and Suzuki, K. T., Arsenic round the world: a review. Talanta, 2002, 58, 201-235.

5. USEPA, Arsenic occurrence in public drinking water supplies. US Environmental Protection Agency, Washington, DC, 2007, EPA815-R-00-023, pp. 1-156.

6. Mohan, D. and Charles, P., Arsenic removal from water/ wastewater using adsorbents - a critical review. J. Hazard. Mater., 2007, 142(1-2), 1-53.

7. Rahman, M. M. et al., Effectiveness and reliability of arsenic field testing kits: are the million dollar screening projects effective or not. Environ. Sci. Technol., 2002, 36(24), 5385-5394.

8. Natale, F. D., Erto, A., Lancia, A. and Musmarra, D., Experimental and modeling analysis of $\mathrm{As}(\mathrm{V})$ ions adsorption on granular activated carbon. Water Res., 2008, 42, 2007-2016.

9. Peggy, A. O., Chemistry and mineralogy of arsenic. Elements, 2006, 2(2), 77-83. doi:10.2113/gselements.2.2.77.
10. WHO, Arsenic compounds, environmental health criteria 224 World Health Organization, Geneva, 2nd edn, 2001

11. USEPA, Federal Register, US Environmental Protection Agency, Washington, DC, 2001, 66(14), 6976-7066.

12. Leupin, O. X. and Hug, S. J., Oxidation and removal of arsenic(III) from aerated groundwater by filtration through sand and zero-valent iron. Water Resour., 2005, 39(9), 1729-1740.

13. Wickramasinghe, S. R., Han, B., Zimbron, J., Shen, Z. and Karim, M. N., Arsenic removal by coagulation and filtration: comparison of groundwater from the United States and Bangladesh. Desalination, 2004, 169(3), 231-244; doi:10.1016/S0011-9164(04)00530-2.

14. Kim, J. and Benjamin, M. M., Modeling a novel ion exchange process for arsenic and nitrate removal. Water Res., 2004, 38(8), 2053-2062; doi:10.1016/j.

15. Weng, Y. H., Chaung-Hsieh, L. H., Lee, H. H., Li, K. C. and Huang, C. P., Removal of arsenic and humic substances (HSs) by electro-ultrafiltration (EUF). J. Hazard. Mater., 2005, 122(1-2), 171-176; doi:10.1016/j.jhazmat.2005.04.001.

16. Jain, C. K. and Singh, R. D., Technological options for the removal of arsenic with special reference to South East Asia: review. J. Environ. Manage., 2012, 107, 1-18.

17. Sud, D., Mahajan, G. and Kaur, M. P., Agricultural waste material as potential adsorbent for sequestering heavy metal ions from aqueous solutions: a review. Bioresour. Technol., 2008, 99, 60176027; doi:10.1016/j.biortech.2007.11.064.

18. Tiwari, M., Shukla, S. P., Mohan, D., Bhargava, D. S. and Kisku, G. C., Modified cenospheres as an adsorbent for the removal of disperse dyes. Adv. Environ. Chem., 2015, 2015, 1-8.

19. Qaiser, S., Saleemi, A. R. and Ahmad, M. M., Heavy metal uptake by agro based waste materials. Environ. Biotechnol., 2007, 10, 409-416.

20. Mohan, D. et al., Sorption of arsenic, cadmium, and lead by chars produced from fast pyrolysis of wood and bark during bio-oil production. J. Colloid Interface. Sci., 2007, 310(1), 57-73.

21. Wang, J. and Chen, C., Biosorbents for heavy metals removal and their future: review. Biotechnol. Adv., 2009, 27, 195-226.

22. Babu, B. V. and Gupta, S., Adsorption of $\mathrm{Cr}(\mathrm{VI})$ using activated neem leaves: kinetic study. Adsorption, 2008, 13, 85-92.

23. Montagnaro, F. and Santoro, L., Reuse of coal combustion ashes as dyes and heavy metal adsorbents: effect of sieving and demineralization on waste properties and adsorption capacity. Chem. Eng. J., 2009, 150, 174-180.

24. Wang, S., Boyjoo, Y., Choueib, A. and Zhu, Z. H., Removal of dyes from aqueous solution using fly ash and red mud. Water Res., 2005, 39, 129-138.

25. APHA, Standard method for the examination of water and wastewater, American Water Works Association and Water Pollution Control Federation, Washington, 22nd edn, 2012.

26. Singh, T. S. and Pant, K. K., Equilibrium, kinetics and thermodynamic studies for adsorption of As(III) on activated alumina. Sep. Purif. Technol., 2004, 36, 139-147.

27. Vaishya, R. C. and Gupta, S. K., Modeling arsenic(V) removal from water by sulfate modified iron-oxide coated sand (SMIOCS). J. Chem. Technol. Biotechnol., 2002, 78, 73-80.

28. Jeong, Y., Maohong, F., Leeuwen, J. V. and Belczyk, J. F., Effect of competing solutes on arsenic(V) adsorption using iron and aluminum oxides. J. Environ. Sci., 2007, 19, 910-919.

29. Tamas, M. J., Sharma, S. K., Ibstedt, S., Jacobson, T. and Christen, P., Heavy metals and metalloids as a cause for protein misfolding and aggregation. Biomolecules, 2014, 4, 252-267.

30. Salman, M., Athar, M., Shafique, M., Din, M. I., Rehman, R., Akram, A. and Ali, S. Z., Adsorption modeling of alizarin yellow on untreated and treated charcoal. Turkish J. Eng. Environ. Sci., 2011, 35, 209-216; doi:10.3906/muh-1009-32.

31. Carabante, I., Grahn, M., Holmgren, A., Kumpiene, A. and Hedlund, J., Adsorption of As(V) on oxide nanoparticle films studied by in situ ATR-FTIR spectroscopy. Colloids Surf. A: Physicochem. Eng. Asp., 2009, 346, 106-113. 
32. Katsoyiannis, I. A. and Zouboulis, A. I., Application of biological processes for the removal of arsenic from ground waters. Water Res., 2004, 38, 17-26; doi:10.1016/j.watres.2003.09.011.

33. Shipley, H. J., Yean, S., Kan, A. T. and Tomson, M. B., Adsorption of arsenic to magnetite nanoparticles: effect of particle concentration, $\mathrm{pH}$, ionic strength, and temperature. Environ. Toxicol. Chem., 2009, 28(3), 509-515.

34. Markandeya, et al., Adsorptive capacity of sawdust for the adsorption of MB dye and designing of two-stage batch adsorber. Cogent Environ. Sci., 2015, 1(1), 1075856.

35. Shukla, S. P., Sonam, Markandeya, Mohan, D. and Pandey, G., Removal of fluoride from aqueous solution using Psidium guajava leaves. Desalin. Water Treat., 2017, 62, 418-425.

36. Langmuir, I., The adsorption of gases on plane surfaces of glass, mica and platinum. J. Am. Chem. Soc., 1916, 40, 1361-1403.

37. Freundlich, H. Z., Over the adsorption in solution. J. Phys. Chem., 1906, 57, 385-470.

38. Temkin, M. J. and Pyzhev, V., Kinetics of ammonia synthesis on promoted iron catalysts. Acta Physiochim. URRS, 1940, 12, $217-$ 222.

39. Redlich, O. and Peterson, D. L., A useful adsorption isotherm. J. Phys. Chem., 1959, 63, 1024-1029.

40. Markandeya, Dhiman, N., Shukla, S. P. and Kisku, G. C., Statistical optimization of process parameters for removal of dyes from wastewater on chitosan cenospheres nanocomposite using response surface methodology. J. Clean. Prod., 2017, 149, 597-606.

41. Markandeya, Shukla, S. P. and Dhiman, N., Characterization and adsorption of disperse dyes from wastewater onto cenospheres activated carbon composites. Environ. Earth Sci., 2017, 76, 702714.

42. Markandeya, Shukla, S. P., Dhiman, N., Mohan, D., Kisku, G. C. and Roy, S., An efficient removal of disperse dye from wastewater using zeolite synthesized from cenospheres. J. Hazard., Toxic, Radio. Waste, 2017, 21(4), 04017017.

43. Markandeya, Shukla, S. P. and Mohan, D., Toxicity of disperse dyes and its removal from wastewater using various adsorbents: a review. Res. J. Environ. Toxicol., 2017, 9, 1-18.

44. Weber, W. J., Matcalf, R. L. and Pitts, J. N., Adsorption in Physicochemical Process for Water Quality Control, Wiley Intersci., New York, 1972, pp. 199-259.
45. Mamy, L. and Barriuso, E., Desorption and time-dependent sorption of herbicides in soils. Eur. J. Soil Sci., 2006, 58, 174-187.

46. Feng-Chin, W., Bing-Lan, L., Keng-Tung, W. and Ru-Ling, T., A new linear form analysis of Redlich-Peterson isotherm equation for the adsorptions of dyes. Chem. Eng. J., 2010, 162, 21-27.

47. Kisku, G. C., Markandeya, Shukla, S. P., Singh, D. S. and Murthy, R. C., Characterization and adsorptive capacity of coal fly ash from aqueous solutions of disperse blue and disperse orange dyes. Environ. Earth Sci., 2015, 74(2), 1125-1135.

48. Tiwari, M., Shukla, S. P., Bhargava, D. S. and Kisku, G. C., Color removal potential of coal fly ash-a low cost adsorbent from aqueous solutions of disperse dyes used in textile mill through batch technique. Our Earth, 2013, 10(4), 5-8.

49. Markandeya, Dhiman, N., Shukla, S. P., Mohan, D., Kisku, G. C. and Patnaik, S., Comprehensive remediation study of disperse dyes containing wastewater by using environmental benign, low cost cenospheres nanosyntactic foam. J. Clean. Prod., 2018, 182, 206-216.

50. Markandeya, Shukla, S. P. and Kisku, G. C., Linear and non-linear kinetic modeling for the adsorption of disperse dye in a batch process. Res. J. Environ. Toxicol., 2015, 9(6), 320-331.

51. Chien, S. H. and Clayton, W. R., Application of Elovich equation to the kinetics of phosphate release and sorption in soils. Soil Sci. Soc. Am. J., 1980, 44(2), 265-268.

52. Weber, W. J. and Morris, J. C., Kinetics of adsorption on carbon from solution. J. Sanit. Eng. Div., 1963, 89, 31-60.

53. Shukla, S. P. et al., Minimization of contact time for two-stage batch adsorber design using second-order kinetic model for adsorption of methylene blue (MB) on used tea leaves. Int. J. Innov. Sci. Res., 2014, 2(1), 58-66.

54. Bhargava, D. S. and Bhatt, D. J., Model for moving media reactor performance. J. Environ. Eng., 1985, 111(5), 618-633.

ACKNOWLEDGEMENTS. The authors thank the Director, IIT (BHU), Varanasi for providing necessary facilities for carrying out this research work.

Received 31 March 2018; revised accepted 15 November 2018

doi: $10.18520 / \mathrm{cs} / \mathrm{v} 117 / \mathrm{i} 4 / 649-661$ 